\title{
COMPARING THE CLINICAL DIAGNOSIS AND PER-OPERATIVE FINDINGS OF ACUTE APPENDICITIS WITH MODIFIED ALVARADO SCORING SYSTEM
}

\author{
Muthu Sankaralingam ${ }^{1}$, Karthikeyan Periyakaruppan ${ }^{2}$ \\ ${ }^{1}$ Assistant Professor, Department of Surgery, Government Theni Medical College, Theni. \\ ${ }^{2}$ Assistant Professor, Department of Surgery, Government Theni Medical College, Theni.
}

\section{ABSTRACT}

\section{BACKGROUND}

Appendicectomy for appendicitis is the most commonly performed emergency operation in the world. Alvarado scoring system is a very commonly used scoring system in appendicitis. This score varies depending upon the population in the area and the clinical setting. This study is to know the value of clinical diagnoses in appendicitis by comparing with modified Alvarado scoring system, and confirm with post-operative histopathological findings of respective cases.

\section{MATERIALS AND METHODS}

This is a prospective study of 100 patients admitted during the period of June 2009 to November 2011 and diagnosed clinically as acute appendicitis. Decision to operate was based only on clinical judgment not by scoring system. But the findings were compared with Modified Alvarado scoring system (excluding shift to left).

\section{RESULTS}

In this prospective study, 100 patients admitted in Thanjavur Medical College during the period of June 2009 to November 2011 and diagnosed clinically as acute appendicitis were included. In our study, negative appendicectomy rate was $18 \%$ in total, out of which, males outnumber the females (Males - 18\% \& Females - 10\%). Diagnostic accuracy of clinical examination was $82 \%$. Diagnostic accuracy in male patients was $87.5 \%$. Diagnostic accuracy in female patients was $72.2 \%$. Out of 100 patients, 66 patients were within the age group 10-30 years. None of the patient had Alvarado score below 4. If the patient had Alvarado score of 5, chance of getting positive histopathological finding was $22 \%$. If the patient had Alvarado score of 6 , chance of getting positive histopathological finding was 68\%. If the patient had Alvarado score of 7, chance of getting positive histopathological finding was $87 \%$. If the patient had Alvarado score above 7, chance of getting positive histopathological finding was $100 \%$.

\section{CONCLUSION}

This study is to know the value of clinical diagnoses in appendicitis by correlating the post-operative histopathological findings of respective cases. Alvarado scoring system is a very commonly used scoring system in appendicitis. There is a significant association between HPE report and intra-operative findings of the respondents and their scores.

\section{KEYWORDS}

Alvarado Score, Acute Appendicitis, Histopathological Report.

HOW TO CITE THIS ARTICLE: Sankaralingam M, Periyakaruppan K. Comparing the clinical diagnosis and per-operative findings of acute appendicitis with modified Alvarado scoring system. J. Evolution Med. Dent. Sci. 2017;6(33):2705-2709, DOI: $10.14260 /$ Jemds/2017/584

\section{BACKGROUND}

Appendicectomy for appendicitis is the most commonly performed emergency operation in the world.

Appendicitis is most commonly seen in second or third decade with slight male predominance (1.2 to $1.3: 1$ ).

In spite of technologic advances, the diagnosis of appendicitis is still based on patient history and physical examination. Prompt diagnosis and early intervention reduce the risk of perforation and prevent complication especially in extremes of age. ${ }^{1}$

Financial or Other, Competing Interest: None.

Submission 26-03-2017, Peer Review 15-04-2017,

Acceptance 17-04-2017, Published 24-04-2017.

Corresponding Author:

Muthu Sankaralingam,

\#5, Srisai Nagar, Muthuthevanpatty,

Theni- 625531.

E-mail: muthusankaralingam7@gmail.com

DOI: $10.14260 /$ jemds $/ 2017 / 584$

\section{(c) (i) $\odot$}

Mortality rate in non-perforated appendicitis is less than $1 \%$, but in perforated appendicitis it is up to $5 \%$, thus negative appendectomy is acceptable to prevent complication and reduce mortality.

This study is to know the value of clinical diagnoses in appendicitis by correlating the post-operative histopathological findings of respective cases. Alvarado scoring system is a very commonly used scoring system in appendicitis. $^{2}$ This score is varied depending upon the population in the area and the clinical setting.

In this scoring, by using pre-tested questionnaire, data were collected and analysed by using SPSS statistical computer software. All patients underwent surgery based on the clinical evaluation. The scores were cross tabulated.

\section{The Objectives of this Clinical study are}

- To find out the importance of clinical diagnosis in acute appendicitis by comparing with operative histopathological examination.

- To study the clinical presentation of appendicitis in TMCI-1. 
- To study the accuracy of modified Alvarado scoring system in diagnosing acute appendicitis.

\section{MATERIALS AND METHODS}

This is a prospective study of 100 patients admitted in Thanjavur Medical College during the period of June 2009 to November 2011 and diagnosed clinically as acute appendicitis.

\section{Methods}

All patients were admitted as emergency.

Detailed history and clinical examination, blood investigation (total count, differential count), plain x-ray abdomen was done and documented in proforma.

Patients with urological, gynaecological or surgical problems other than appendicitis were excluded from this study.

Decision to operate was based only on clinical judgment not by scoring system. But the findings were compared with Modified Alvarado scoring system (excluding shift to left). Informed written consent was obtained.

Preoperative antibiotics were given to all patients.

All patients were operated under Regional or General Anaesthesia.

Appendicectomy was done by open method by Lanz, McBurney, or mid line depending on pre-operative findings.

Intra-operatively macroscopic appearance of appendix was documented.

All appendicectomy specimens were sent to Department of Pathology at TMCH for histopathological examination, microscopic findings were correlated with the Alvarado scoring and clinical diagnosis.

Postoperatively, patients were given antibiotics and discharged on 4th day except in cases of complication.

\section{RESULTS}

In this prospective study, 100 patients admitted in Thanjavur Medical College during the period of June 2009 to November 2011 and diagnosed clinically as acute appendicitis were included.

The incidence of appendicitis according to the age distribution is shown in Table 1, Fig. 1. According to this, highest age distribution of 36 patients was seen between 21 30 years. (36\%).

Males are most affected than females i.e. 66 patients $(60 \%)$ and females were $34 \%$ as in Table 2, Fig. 2.

\begin{tabular}{|c|c|c|c|c|c|}
\hline \multicolumn{7}{|c|}{} & Frequency & $\%$ & $\begin{array}{c}\text { Valid } \\
\%\end{array}$ & $\begin{array}{c}\text { Cumulative } \\
\%\end{array}$ \\
\hline \multirow{7}{*}{} & $\begin{array}{c}\text { Below } \\
20 \text { yrs. }\end{array}$ & 30 & 30.0 & 30.0 & 30.0 \\
\cline { 2 - 6 } & $21-30$ yrs. & 36 & 36.0 & 36.0 & 36.0 \\
\cline { 2 - 6 } Valid & $31-40$ yrs. & 19 & 19.0 & 19.0 & 19.0 \\
\cline { 2 - 6 } & 41.50 yrs. & 6 & 6.0 & 6.0 & 6.0 \\
\cline { 2 - 6 } & $\begin{array}{c}51 \text { yrs. \& } \\
\text { above }\end{array}$ & 9 & 9.0 & 9.0 & 9.0 \\
\cline { 2 - 6 } & Total & $\mathbf{1 0 0}$ & $\mathbf{1 0 0 . 0}$ & $\mathbf{1 0 0 . 0}$ & \\
\hline \multicolumn{6}{|c|}{ Table 1. Incidence of Appendicitis According to Age } \\
\hline
\end{tabular}

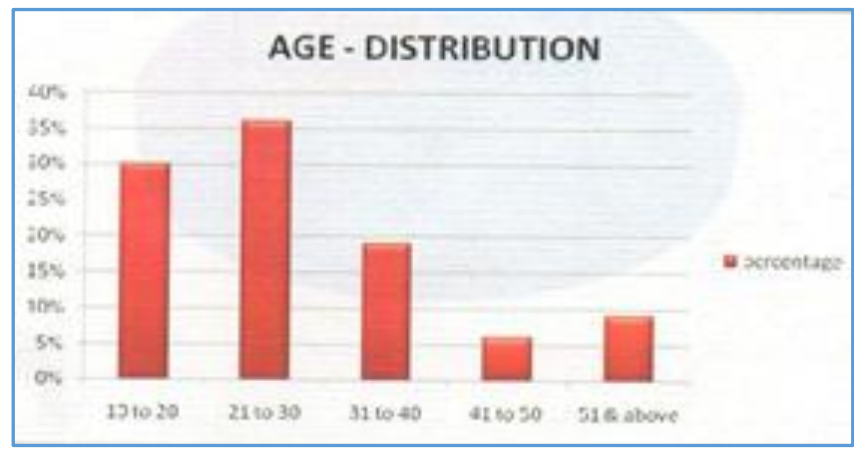

Figure 1. Incidence of Appendicitis According to Age

\begin{tabular}{|c|c|c|c|c|c|}
\hline \multicolumn{2}{|c|}{} & Frequency & $\%$ & $\begin{array}{c}\text { Valid } \\
\%\end{array}$ & $\begin{array}{c}\text { Cumulative } \\
\%\end{array}$ \\
\hline \multirow{3}{*}{ Valid } & Male & 66 & 66.0 & 66.0 & 66.0 \\
\cline { 2 - 6 } & Female & 34 & 34.0 & 34.0 & 100.0 \\
\cline { 2 - 6 } & Total & $\mathbf{1 0 0}$ & $\mathbf{1 0 0 . 0}$ & $\mathbf{1 0 0 . 0}$ & \\
\hline \multicolumn{6}{|c|}{ Table 2. Gender Distribution } \\
\hline
\end{tabular}

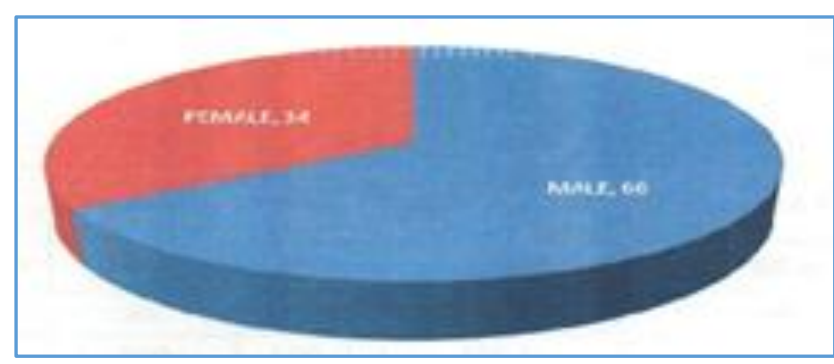

Figure 2. Shows the Gender Distribution

In Alvarado scoring, the score was given to the patient from 5 to 9 . According to the table 3, the highest frequency was seen in patient with score $7(31 \%)$, next in score 8 (29\%). Patients with the score above 7 were taken for surgery without any other imaging studies. According to table 4 , scores above 7 were $35 \%$ and below were $65 \%$.

\begin{tabular}{|c|c|c|c|c|c|}
\hline \multicolumn{2}{|c|}{} & Frequency & $\%$ & $\begin{array}{c}\text { Valid } \\
\%\end{array}$ & $\begin{array}{c}\text { Cumulative } \\
\%\end{array}$ \\
\hline \multirow{4}{*}{ Valid } & 5.00 & 9 & 9.0 & 9.0 & 9.0 \\
\cline { 2 - 6 } & 6.00 & 25 & 25.0 & 25.0 & 34.0 \\
\cline { 2 - 6 } & 7.00 & 31 & 31.0 & 31.0 & 65.0 \\
\cline { 2 - 6 } & 8.00 & 29 & 29.0 & 29.0 & 94.0 \\
\cline { 2 - 6 } & 9.00 & 6 & 6.0 & 6.0 & 100.0 \\
\cline { 2 - 6 } & Total & $\mathbf{1 0 0}$ & $\mathbf{1 0 0 . 0}$ & $\mathbf{1 0 0 . 0}$ & \\
\hline \multicolumn{6}{|c|}{ Table 3. Alvarado Scoring } \\
\hline
\end{tabular}

\begin{tabular}{|c|c|c|c|c|c|}
\hline \multicolumn{2}{|c|}{} & Frequency & $\%$ & $\begin{array}{c}\text { Valid } \\
\%\end{array}$ & $\begin{array}{c}\text { Cumulative } \\
\%\end{array}$ \\
\hline \multirow{3}{*}{ Valid } & Below 7 & 65 & 65.0 & 65.0 & 65.0 \\
\cline { 2 - 6 } & Above 7 & 35 & 35.0 & 35.0 & 100.0 \\
\cline { 2 - 6 } & Total & $\mathbf{1 0 0}$ & $\mathbf{1 0 0 . 0}$ & $\mathbf{1 0 0 . 0}$ & \\
\hline \multicolumn{6}{|c|}{ Table 4. Score } \\
\hline
\end{tabular}

\begin{tabular}{|c|c|}
\hline Alvarado Scoring & Percentage of Positivity \\
\hline 05 & 22 \\
\hline 06 & 68 \\
\hline 07 & 87 \\
\hline More than 7 & 100 \\
\hline
\end{tabular}




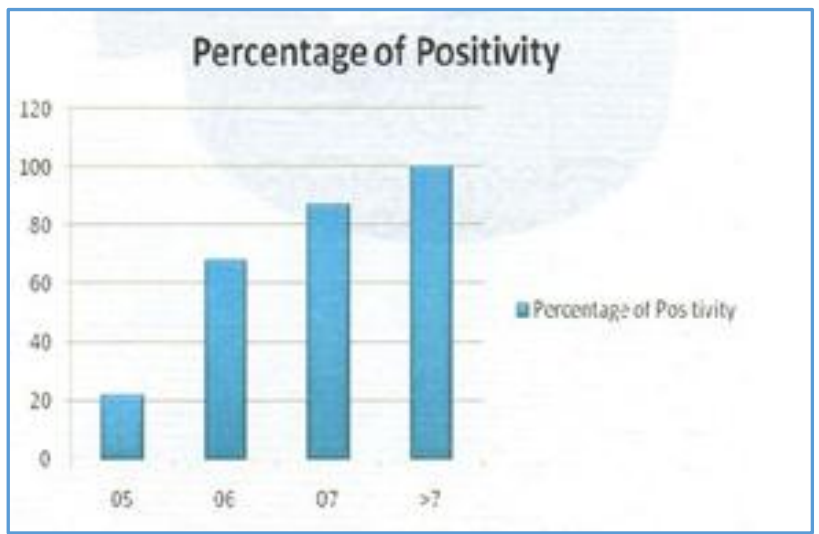

Figure 3

According to Table 4, patients with Alvarado scoring above 7 were 35 and the percentage of positivity by comparing with histopathological diagnosis was $100 \%$. The confirmed histopathological diagnosis obtained from the pathology department was given in the Table 6.

\begin{tabular}{|c|c|}
\hline Pathology & Total No. of Cases \\
\hline Acute appendicitis & 72 \\
\hline Fulminant & 23 \\
\hline Appendicular perforation & 1 \\
\hline Appendicular Abscess & 4 \\
\hline \multicolumn{2}{|c|}{ Table 6. Histopathology Diagnosis Obtained } \\
\hline
\end{tabular}

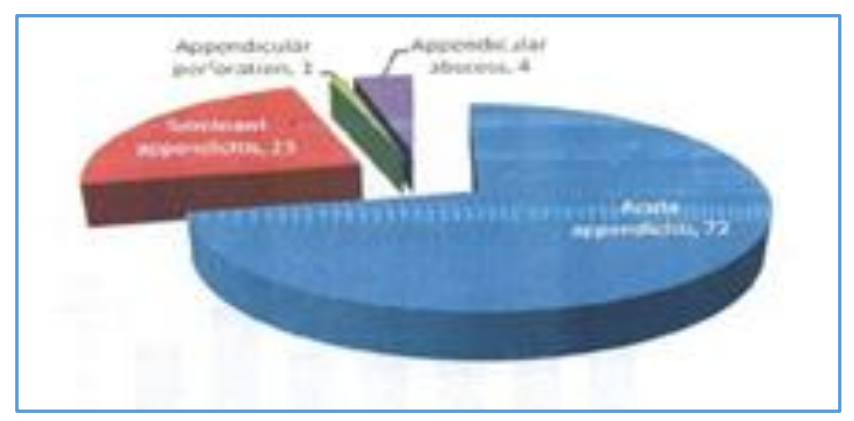

Histopathological correlation was obtained. $72 \%$ of the cases were acute appendicitis and fulminant appendicitis cases were $23 \%$. Appendicular perforation was in one case and abscess was in 4 cases as shown in Table 6, Fig. 4.

\begin{tabular}{|c|c|}
\hline Clinical Presentation & Percentage \\
\hline Migrating umbilical pain & 67 \\
\hline Anorexia & 96 \\
\hline Nausea & 62 \\
\hline RIF Tenderness & 97 \\
\hline Rebound Tenderness & 80 \\
\hline Elevated Temperature & 70 \\
\hline Leucocytosis & 62 \\
\hline \multicolumn{2}{|c|}{ Table 7. Clinical Presentation } \\
\hline
\end{tabular}

The most important clinical manifestation is the RIF tenderness (97\%), Anorexia (96\%). The other manifestations were rebound tenderness (80\%), elevated temperature (70\%), migrating umbilical pain (67\%), nausea and leucocytosis were about $62 \%$ respectively as shown in Table 7, Fig. 5.

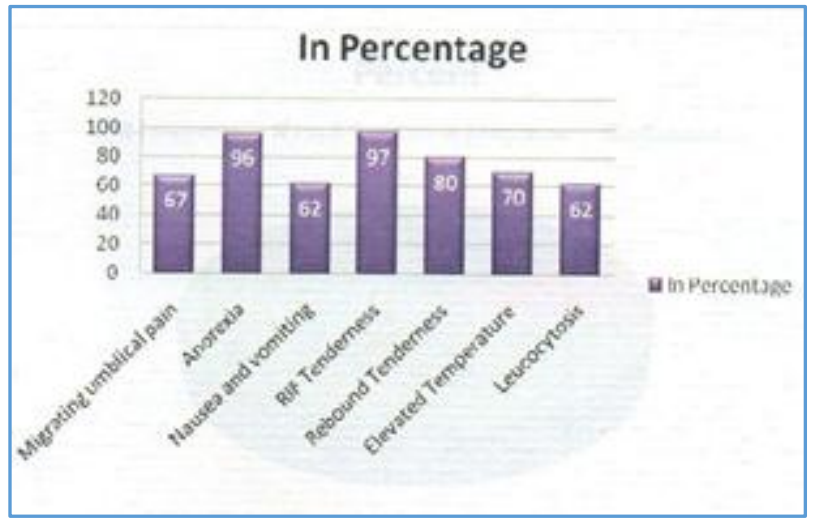

Figure 5

Commonest per-operative findings were congestion (18\%), pus, gangrene, perforation in $12 \%$ of cases and inflammation was in 70\%, which is shown in Table 8, Fig. 6.

\begin{tabular}{|c|c|c|}
\hline Per Operative Findings & Percent & Valid Percent \\
\hline Congestion & 18 & 18 \\
\hline Pus \& Gangrene \& perforation & 12 & 12 \\
\hline Inflamed & 70 & 70 \\
\hline \multicolumn{3}{|c|}{ Table 8. Per-operative Findings } \\
\hline
\end{tabular}

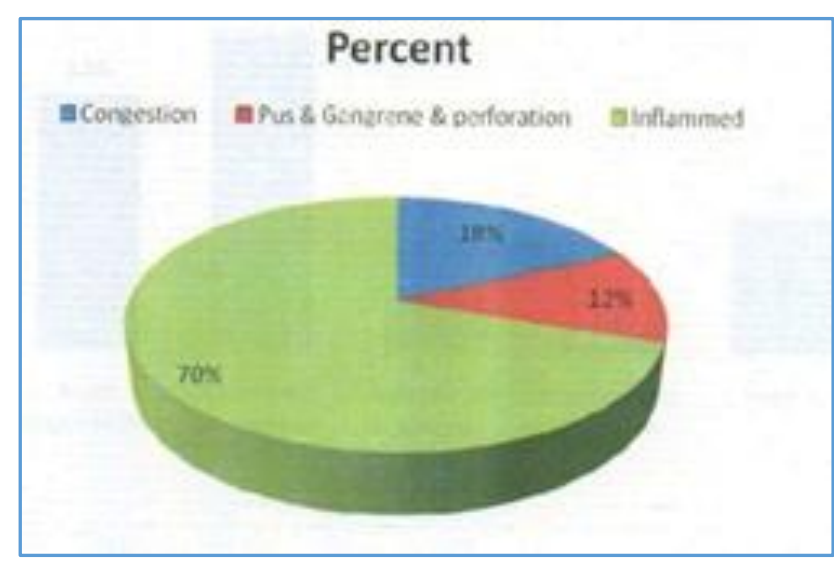

Figure 6

\begin{tabular}{|c|c|c|}
\hline Age & Positive Finding & Negative Finding \\
\hline $10-20$ & 06 & 06 \\
\hline $21-30$ & 11 & 03 \\
\hline $31-40$ & 04 & 01 \\
\hline $41-50$ & 02 & 00 \\
\hline 50 above & 01 & 00 \\
\hline
\end{tabular}

Table 9. In Females, Positive/negative Finding Ratio based on Post-operative HPE Report

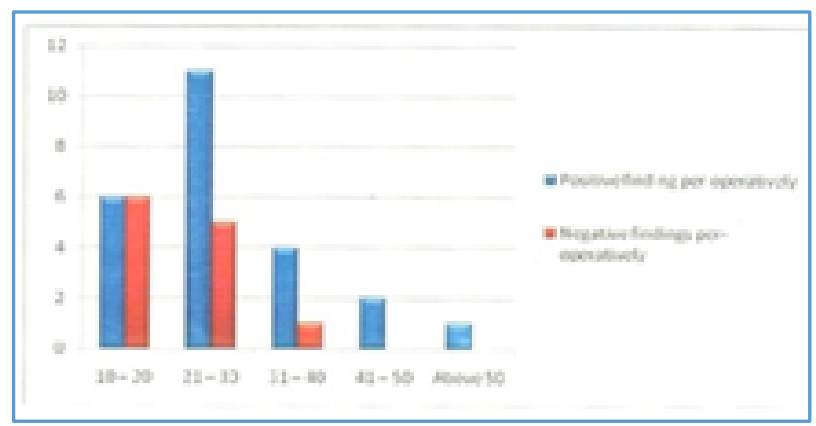

Figure 7 
Among the 34 female patients, positive findings were seen in 24 patients and 10 patients were having negative findings. Among the 24 individuals with positive findings, 6 patients were in age group of 10-20 yrs., 11 in 21-30 yrs., 4 in 31-40 yrs., 2 in 41-50 yrs. and one patient was above 50 yrs.

In 10 negative finding cases, 6 were in age group of 10-20 yrs., 3 were in 21-30 yrs. and one patient was between 31-40 yrs. as shown in Table 9, Fig. 7.

\begin{tabular}{|c|c|c|}
\hline Age & $\begin{array}{c}\text { Positive Finding } \\
\text { Per-operatively }\end{array}$ & $\begin{array}{c}\text { Negative Finding } \\
\text { Per-operatively }\end{array}$ \\
\hline $10-20$ & 15 & 03 \\
\hline $21-30$ & 20 & 02 \\
\hline $31-40$ & 11 & 03 \\
\hline $41-50$ & 04 & 00 \\
\hline 50 above & 06 & 02 \\
\hline \multicolumn{2}{|c|}{ Table 10. Male Positive/Negative Finding Ratio } \\
\hline
\end{tabular}

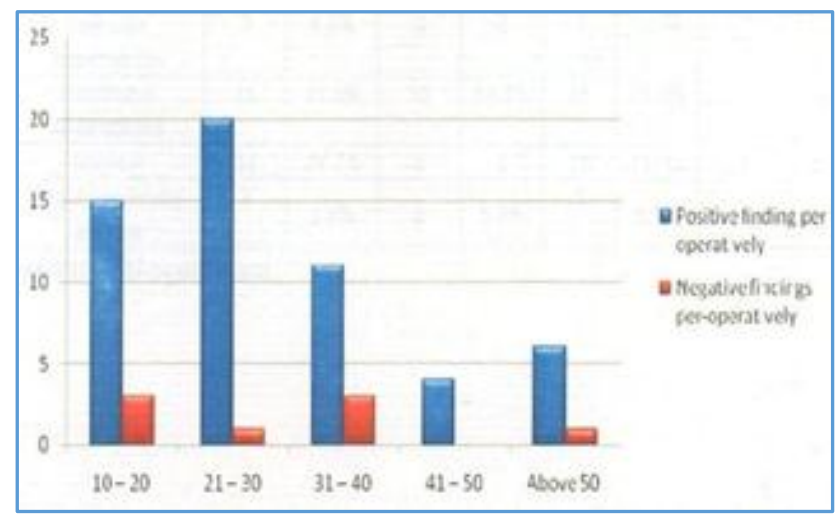

Among the 66 male patients, positive findings were seen per-operatively in 56 individuals and negative findings were seen in 10 patients. Among the 56 patients, 15 patients were in age group of 10-20 yrs., 20 were in 21-30 yrs., 11 were in age group of 31-40 yrs., 4 were in $41-50$ yrs. and 6 patients were above 50 yrs. of age group.

Among the 10 individuals with negative findings, 3 were in age group of 10-20 yrs., 2 were in 21-30 yrs., 3 were in 3140 yrs. and 2 were above 50 yrs. of age group as shown in Table 10, Fig. 8.

Per-op Finding * Score

\begin{tabular}{|l|l|l|}
\hline $\mathrm{X}^{2}=54.762$ & $\mathrm{DF}=41$ & $0.074(<0.05)$ significant \\
\hline
\end{tabular}

The above table shows that there is a significant association between intra-operative findings of the respondents and their scores. Hence, the study is significant.

\section{DISCUSSION}

Acute appendicitis is one of the most common abdominal emergencies in surgery and diagnosis is purely based only on clinical judgment. Also, it can lead to fatal complications, if the diagnosis is overlooked. So the possibility of negative appendicectomy is high in order to prevent the complications.
In our study, negative appendicectomy rate was $18 \%$ in total in which males outnumber the females (male - 18\% \& female $-10 \%$ ).

\section{In Females}

In the age group of 10-20 years, total number of cases operated was 12. Out of these, 5 cases had positive histopathology and 6 cases had negative histopathology.

In 20-30 years age group, 16 cases were operated. Out of these, 11 cases had positive histopathology \& 5 cases had negative histopathology.

In 30-40 years age group, total number of cases operated was 5 . Out of these, 4 cases were histopathologically positive and 1 case was histopathologically negative. In age above 40 years, all cases were histopathologically proven as appendicitis.

\section{In Males}

In 10-20 years of age group, 18 cases were operated. Out of these, 15 cases were diagnosed as appendicitis. In 3 cases, appendix was normal.

In 20-30 years of age group, 21 cases were operated. Out of these, 20 cases were diagnosed as appendicitis and in one case appendix was normal.

In 30-40 years of age group, 14 cases were operated. Out of these, 11 cases were diagnosed as appendicitis. In 3 cases, appendix was normal.

In age above 40 years, 15 cases were operated. Out of these, 10 cases were diagnosed as appendicitis.

\begin{tabular}{|c|c|c|}
\hline $\begin{array}{c}\text { Sl. } \\
\text { No. }\end{array}$ & Studies & $\begin{array}{c}\text { Negative } \\
\text { Appendicectomy } \\
\text { Rate }\end{array}$ \\
\hline 1 & Ali Mohamed et al (2005) & $21 \%$ \\
\hline 2 & Rasool Buxbehan et al (2008) & $18.6 \%$ \\
\hline 3 & Subhajed Dey et al (2009) & $13 \%$ \\
\hline 4 & $\begin{array}{c}\text { Mudassir Maqbool Wani } \\
\text { et al (2007) }\end{array}$ & $32.3 \%$ \\
\hline 5 & $\begin{array}{c}\text { Syed Waris Ali Shah } \\
\text { et al (2007) }\end{array}$ & $11.1 \%$ \\
\hline \multicolumn{2}{|c|}{ Our study } & $\mathbf{1 8 \%}$ \\
\hline \multicolumn{2}{|c|}{ Table 12. Comparison with Other Studies $3,4,5$} \\
\hline
\end{tabular}

\section{Regarding Sex}

Males had higher incidence of acute appendicitis than females. Male and female ratio in our study was 1.7:1.

\begin{tabular}{|c|c|}
\hline Studies & Male: Female \\
\hline Rasool Buxbehan et al & $1.94: 1$ \\
\hline Ali Mohamed et al & $1.2: 1$ \\
\hline Our study & $1.7: 1$ \\
\hline Table 13. Comparison with Other Studies ${ }^{6,7,8}$ \\
\hline
\end{tabular}

\section{Reading Diagnostic Accuracy}

Diagnostic accuracy of clinical examination was $82 \%$. Diagnostic accuracy in male cases was $87.5 \%$.

Diagnostic accuracy in female cases was $72.2 \%$.

\begin{tabular}{|c|c|}
\hline Studies & Percentage of Diagnostic Accuracy \\
\hline Our study & $82 \%$ \\
\hline Ali Mohamed et al & $76 \%$ \\
\hline \multicolumn{2}{|c|}{ Table 14. Comparison with Other Studies 9,10} \\
\hline
\end{tabular}




\section{Reading Age}

Out of 100 patients, 66 patients were within the age group of 10-30 years.

\begin{tabular}{|c|c|}
\hline Studies & Total No. of Cases \\
\hline Our study & 66 cases \\
\hline Ali Mohamed et al & 61 cases \\
\hline \multicolumn{2}{|c|}{ Table 15. Comparison with Other Studies } \\
\hline
\end{tabular}

Table 16 Shows Clinical Presentation with other studies

\begin{tabular}{|c|c|c|c|}
\hline Studies & $\begin{array}{c}\text { Our } \\
\text { Study }\end{array}$ & $\begin{array}{c}\text { Ali } \\
\text { Mohamed } \\
\text { et al }\end{array}$ & $\begin{array}{c}\text { Rasool } \\
\text { Buxbehan } \\
\text { et al }\end{array}$ \\
\hline $\begin{array}{c}\text { Migrating } \\
\text { umbilical pain }\end{array}$ & $67 \%$ & $82 \%$ & $47 \%$ \\
\hline Anorexia & $96 \%$ & $87 \%$ & $80.7 \%$ \\
\hline $\begin{array}{c}\text { Nausea and } \\
\text { vomiting }\end{array}$ & $62 \%$ & $67 \%$ & $67.4 \%$ \\
\hline RIF Tenderness & $97 \%$ & $100 \%$ & - \\
\hline $\begin{array}{c}\text { Rebound } \\
\text { Tenderness }\end{array}$ & $80 \%$ & $90 \%$ & - \\
\hline \multicolumn{2}{|c|}{ Table 16. Comparison with Other Studies 13,14 } \\
\hline
\end{tabular}

\section{Regarding Alvarado Scoring System}

None of the patient had Alvarado score below 4.

If the patient had Alvarado score of 5 , chance of getting positive histopathological finding was $22 \%$.

If the patient had Alvarado score of 6 , chance of getting positive histopathological finding was $68 \%$.

If the patient had Alvarado score of 7 , chance of getting positive histopathological finding was $87 \%$.

If the patient had Alvarado score above 7, chance of getting positive histopathological finding was $100 \%$.

\begin{tabular}{|c|c|}
\hline Studies & $\begin{array}{c}\text { Percentage of Positivity if } \\
\text { Alvarado Score }>7\end{array}$ \\
\hline $\begin{array}{l}\text { Rasool Buxbehan } \\
\text { et al }\end{array}$ & $100 \%$ \\
\hline Our study & $100 \%$ \\
\hline \multicolumn{2}{|c|}{ Table 17. Comparison with Other Studies $15,16,17$} \\
\hline
\end{tabular}

Statistical analysis was done by comparing HPE report with Alvarado score and comparing intra-operative finding with Alvarado score study, significant with $\mathrm{P}$ value of 0.001 , 0.74 respectively.

\section{Limitations of the Study}

As this study compared the clinical diagnosis with the Alvarado scoring system and correlated with the histopathological report, the sensitivity, specificity, positive predictive value and negative predictive value of the clinical diagnosis with Alvarado scoring and with histopathological report were not done due to small study sample.

\section{CONCLUSIONS}

1. Acute appendicitis is one of the most common abdominal emergencies in surgery.

2. Males had higher incidence of acute appendicitis than females.

3. Diagnostic accuracy of clinical examination was $82 \%$.

4. Out of 100 patients, 66 patients were within the age group of 10-30 years.
5. If the patient had Alvarado score above 7, chance of getting positive histopathological finding is $100 \%$.

In spite of recent advances in medical technology, clinical judgement remains of great value in the diagnosis of acute appendicitis.

\section{REFERENCES}

[1] Radford-Smith GL, Edwards JE, Purdie DM, et al Protective role of appendicectomy on onset and severity of ulcerative colitis and Crohn's disease. Gut 2002;51(6):808-813.

[2] van Randen A, Bipat S, Zwinderman AH, et al. Acute appendicitis: meta -analysis of diagnostic performance of CT and graded compression us related to prevalence of disease. Radiology 2008;249:97-106.

[3] Doria AS, Moineddin R, Kellenberger C, et al. US or CT for diagnosis of appendicitis in children and adults? a meta analysis. Radiology 2006;241(1):83-94.

[4] Birnhaum BA, Wilson SR. Appendicitis at the millennium. Radiology 2000;215(2):337-48.

[5] CoblJen L, Groot I, Kingrna L, et al. A simple M'RI protocol in patient with clinically suspected appendicitis results in 138 patients and effect on outcome of appendicectomy. Eur Radiol 2009;19(5):1175-83.

[6] Pedrasa L, Levine D, Eyvazzadeh AD, et al. MR imaging evaluation of acute appendicitis in pregnancy. Radiology 2006;238(3):891-9.

[7] Lam M, Singh A, Kaewlai R, et al. MR of acute appendicitis pearls / pitfalls. Curnprobl Diagnosis Radiol 2008;37(2):57-66.

[8] Stephens PL, Mazzucco JJ. Comparison of ultrasound and the Alvarado score for the diagnosis of acute appendicitis. Conn Med 1999;63(3):137-40.

[9] Cuschieri A. The small intestine and vermiform appendix. In: Cuscheri A, Giles GR, Mossa AR, ed. Essential surgical practice. London: Butter worth Heinman 1995:1325-8.

[10] Jaffe B. The appendix. In: Brunicardi FEiC, ed. Schwartz's principles of surgery. New York: McGraw Hill Companies 2005.

[11] Dado G, Anania G, Baccarani U, et al. Application of a clinical score for the diagnosis of acute appendicitis in childhood. J Pediatr Surg 2000;35(9):1320-2.

[12] Paulson EK, Kalady, Pappas TN. Clinical practice. Suspected appendicitis. N E J M 2003;348(3):236-42.

[13] Gilmore OJ, Jones D, Ynag Q. Appendicitis and mimicking conditions. Lancet 1975;2(7932):421-4.

[14] Kalan M, Talbot D, Cunliffe WJ, et al. Evaluation of the modified Alvarado score in the diagnosis of acute appendicitis: a prospective study. Ann R Coll Surg 1994;76(6):418-9.

[15] Ohmann C, Yang Q, Franke C. Diagnostic scores for acute appendicitis. Eur J Surg 1995;161(4):273-81.

[16] Fenyo G, Lindberg G, Blind P, et al. Diagnostic decision support in suspected acute appendicitis: validation of a simplified scoring system. Eur J Surg Med 1997;163(11):831-8.

[17] Alvarado A. A practical score for the early diagnosis of acute appendicitis. Ann Emerg 1986;15(5):557-64. 